Agro-Science Journal of Tropical Agriculture, Food, Environment and Extension Volume 11 Number 3 September 2012 pp 44 - 50

TSSN III9-7455

\title{
ASSESSMENT OF STRUCTURAL STABILITY OF A DEGRADED SANDY CLAY LOAM SOIL UNDER COVER CROPS IN SOUTH-EASTERN NIGERIA
}

\author{
Chinedu $^{1}$ P, P. and Ahamefule ${ }^{2}$, E. H \\ ${ }^{1}$ Department of Soil Science, University of Nigeria, Nsukka 410001, Enugu State, Nigeria \\ ${ }^{2}$ Department of Agronomy, University of Ilorin, Ilorin, Kwara State, Nigeria \\ corresponding author: princechinedupeter@yahoo.co.uk
}

\begin{abstract}
The effects of bare, two legumes and four grasses cover treatments on the structural stability of a sandy clay loam Ultisol were studied within a two year period. The experiment was of a randomised complete block design with seven treatments. The legume treatments were Centrosema pubescens (Ce) and Pueraria phaseoloides (Ps); while the grass treatments were comprised of Panicum maximum (Pm), Cynodon plectostachyus (Cp), Axonopus compressus (Ac) and Pennisetum purpureum $(P p)$. The Organic Matter (OM) content in plots under vegetative cover was significantly $(P<0.05)$ higher than that in the bare plots, with plots under Panicum maximum having the highest organic matter $(O M)$ content $(1.8 \%)$ at first sampling compared to the bare treatment plots which had the least (0.4\%). After twenty four months it was observed that on the average the percentage of the aggregates in the size range exceeding $1.00 \mathrm{~mm}$ was lowest (20.5\%) for soils under the bare treatment compared to those under grass (48.4\%) and legume (35.5\%), indicating that more than a half (54\%) of the aggregates of the bare plots were small sized $(<0.50 \mathrm{~mm}$ diameter) whereas about half of the aggregates of grass treated plots were in the macro-aggregate range. Soils under vegetative cover generally showed significantly higher mean weight diameter $(1.04-1.66 \mathrm{~mm})$ in relation to bare treatment plots $(0.84 \mathrm{~mm})$, with soils under Panicum maximum showing consistently higher $(1.66 \mathrm{~mm})$ mean weight diameter compared to the other vegetative cover treated soils. Soil aggregates under grass treatment had the lowest range of Potential Structural Deformation Index (PSDI) values (14.63 - 20.13\%) compared to aggregates under legume treatment (24.07 - 27.17 \%).The PSDI values indicated that soils under vegetative cover were on the average twice more stable to rain drop impact deformation compared to soils in bare plots.
\end{abstract}

Key words: cover crops, Ultisol, soil structural stability.

\section{INTRODUCTION}

Physical and chemical factors determine the fertility and health of the soil. If emphasis is paid only on chemical factors while neglecting the physical factors, soil physical degradation results. Today, sizeable areas of tropical soils have come under the threat of severe sheet and gully erosion. Notably, in Africa and specifically south-eastern region of Nigeria, there are clear indications of astonishing decline in soil quality properties following removal of natural vegetation which otherwise provides improved physical, chemical and biological properties of the soil over the years (Wilkinson, 1975; Wilkinson and Aina, 1976; Juo and Lal, 1977; Ahamefule and Mbagwu, 2007). Increasing human population density exceeding 500 persons per square kilometre in some parts of south-eastern Nigeria (FAO, 1990) means an increased demand on the use of soils which leaves it degraded. Generally, Ultisols together with Oxisols constitute about $43 \%$ of the soils of the tropics (President's Science Advisory Committee,
1967). The main constraints of these soils with respect to agricultural production are fragility, compactibilty, and high susceptibility to erosion (McBride, 1990). Meaningful efforts at rehabilitating and utilising such soils for sustainable agricultural production should be based on the promotion of land use systems that retain permanent crop cover needed to maintain high level of organic matter and stable structure, and ensure minimal erosion, reduced nutrient leaching, carbon sequestration, weed suppression, and integrated pest management. Cover crops improve soil quality, water retention, reduce nutrient and pesticide runoff, decrease soil erosion, reduce sediment loading, reduce pathogen loading (Dabney, 1996). Well aggregated soils provide stable traction for farm implements, adequate physical conditions for the penetration, growth and anchorage of plant roots as well as free drainage with moderate retention of rainfall (Onwualu and Ahaneku, 2001). Well aggregated soils also resist surface crusting, 
because of the low tendency of the water-stable aggregates to break apart on rain-drop impact. Crusting may lead to a physical condition where plant root or water does not readily penetrate the soil, or where germinating seed cannot break through a soil crust, thereby leading to reduced crop yield even with adequate supply of plant nutrients (Mbagwu and Bazzoffi,1998). Such a condition therefore necessitates a land use strategy which maintains good structural stability of soils. Grass and legume cover crops have been used successfully in many tropical regions for this purpose. Salako (2001) reported increased structural stability with a legume-based soil management system, while Salako et al., (2007) used cover crops for the rehabilitation of a physically degraded and eroded Alfisols in south-western Nigeria. Research results from the northern guinea savannah and the derived guinea savannah region of Nigeria have also shown increased soil structural stability following treatment with cover crops (Wilkinson, 1975; Lal et, al., 1979; Obi, 1999).

Therefore the objectives of this study were:

1. To determine the effectiveness of selected grass and legume cover crops in increasing the structural stability of a degraded sandy clay loam Ultisol in south-eastern Nigeria.

2. To rank the effectiveness of the selected grass and legume cover crops thereby making recommendations on the management of degraded sandy clay loam Ultisols in southeastern Nigeria.

\section{MATERIALS AND METHODS Experimental site}

The study was carried out in the University of Nigeria, Nsukka Experimental Farm (Latitude $06^{\circ} 52^{\prime} \mathrm{N}$; Longitude $07^{\circ} 24^{\prime}$ E) from April 2009 to April 2010. The area is characterised by a humid tropical climate with distinct wet (April to October) and dry (November to March) seasons. The rainfall pattern is bimodal with an average annual total of about $1600 \mathrm{~mm}$. The vegetation is dominated by Imperata cylindrica (Poaceae), Andropogon gayanus (Poaceae), Chromolena africana (Asteraceae) and Pennisetum polystachiom (Poaceae). The soil is deep, porous and red to brownish red in colour and derived from sandy deposits of false-bedded sand-stone, it is classified as a siliceous, kaolinitic and oxic paleustult with an isohyperthermic temperature regime (USDA, Soil Survey Staff, 1975; Akamigbo and Igwe, 1990).

Twenty eight plots, $9.89 \mathrm{~m}^{2}$ each were used for the experiment; there were seven treatments consisting of two legume covers (Pueraria phaseoloides (Ps), Centrosema pubescens $(\mathrm{Ce}))$, five grass covers (Panicum maximum (Pm), Cynodon plectostachyus (Cp), Axonopus compressus (Ac), Pennisetum purperum $(P p))$ and a bare fallow; placed $0.5 \mathrm{~m}$ apart. Each of the treatments was replicated four times in a Randomised Complete Block Design (RCBD). The bare plots were kept weed free Manually. No commercial fertilizer was applied to the plots before and during the experimental period.

\section{Sample collection and preparation}

Soil samples were collected from $0-15 \mathrm{~cm}$ soil depth of each plot in April, 2009 using a spade. Sampling was repeated twelve months after, precisely in April, 2010. Each sample was air dried and passed through a 4.75mm sieve.

\section{Organic matter $(\mathrm{OM})$}

Organic carbon was determined by the dichromate oxidation method of Walkley and Black as modified by Page et al., (1986) and the organic matter content in the soil was computed thus:

$\% \mathrm{Om}=\%$ OC $\times 1.724$

Where $\% \mathrm{Om}=$ percentage organic matter

$\% \mathrm{OC}=$ percentage organic carbon

\section{Determination of soil structural stability Water stable aggregates}

To separate the water stable aggregates, $20 \mathrm{~g}$ samples of the $<4.75 \mathrm{~mm}$ air dried soil samples were put in the top of a nest of sieves of $2.00 \mathrm{~mm}, 1.00 \mathrm{~mm}, 0.50 \mathrm{~mm}$, and $0.25 \mathrm{~mm}$ diameter and pre-soaked in distilled water for 30min (Kemper and Rosenau, 1986). The sieves and their contents were then oscillated vertically once every second in water 20 times, using $4 \mathrm{~cm}$ amplitude. Care was taken to ensure that the soil particles on the topmost sieve were always below the water surface during each oscillation. After wet sieving, the aggregates left on each sieve and the unstable $(<0.25$ $\mathrm{mm}$ ) aggregates were quantitatively transferred into beakers, dried at $50^{\circ} \mathrm{C}$ for $48 \mathrm{hrs}$, weighed and stored. The percentage ratio of the aggregates on each sieve represented the water stable aggregates (WSA) of size classes: $4.75-1.00 \mathrm{~mm}, 1.00-0.50 \mathrm{~mm}, 0.50-0.25 \mathrm{~mm}$ and $<0.25 \mathrm{~mm}$.

\section{Percent water-stable aggregates \\ $\mathrm{S}=\left(\mathrm{M}_{\mathrm{a}} / \mathrm{M}_{\mathrm{t}}\right) \times 100$ \\ Where $\mathrm{S}=$ percent water-stable aggregates $(\%)$ \\ $\mathrm{M}_{\mathrm{a}}=$ mass of the resistant aggregate $(\mathrm{g})$ \\ $\mathrm{M}_{\mathrm{t}}=$ total mass of the soil sieved $(\mathrm{g})$}

\section{Mean weight diameter}

Mean Weight Diameter $\left(\mathrm{MWD}_{\mathrm{w}}\right)$ of wet aggregates was determined from the wet sieving technique (Kemper and Rosenau, 1986) using the following equation:

$\mathrm{MWD}_{\mathrm{w}}=\sum_{i=1}^{n} X_{i} \mathrm{~W}_{i}$

of the total sample weight in the corresponding sieve sizes $(g)$

Larger $\mathrm{MWD}_{\mathrm{w}}$ values indicated higher proportions of macro aggregate and therefore higher stability to water disaggregation. The determination of the mean weight diameter of dry aggregates followed same procedures as in wet sieving with the difference been that rotary sieving technique described in detail by Kemper and Rosenau (1986) was used rather than the wet sieving technique.

Potential structural deformation index

The Potential Structural Deformation Index (PSDI) which estimates the susceptibility of the dry aggregates to disintegrate upon impact with water drops was 
computed according to the method of Mbagwu and Bazzoffi (1998) as follows:

$$
\begin{aligned}
\text { PSDI } & =\left[1-\frac{\sum_{i=1}^{n}\left(\bar{\theta}_{i} w_{i}\right)}{\sum_{i=1}^{n}\left(\bar{\theta}_{i} d_{i}\right)}\right] \times 100 \\
\text { Where: } \bar{\theta}_{i} & =\text { mean diameter of the } \mathrm{i}^{\text {th }} \text { fraction }(\mathrm{mm}) \\
\mathrm{w}_{\mathrm{i}} & =\text { proportion of the total mass retained in }
\end{aligned}
$$

the $\mathrm{i}^{\text {th }}$ size fraction after wet sieving $(\mathrm{g})$

$\mathrm{d}_{\mathrm{i}}=$ proportion of the total mass retained in the

$\mathrm{i}^{\text {th }}$ sieve size after dry sieving $(\mathrm{g})$

$$
\mathrm{n}=\text { number of sieve sizes used }
$$

Degree of structural enhancementThe Degree of Structural Enhancement (DSE) was used to measure soil structural improvement due to treatments. It was calculated using the formula:

DSE $=1-\left(\frac{\text { MWDc }}{M W D t}\right) \times 100$

Where MWDc is the mean weight diameter for control and MWDt is that of treated soil.

Positive values indicate contribution to structural enhancement, whereas negative values indicate no contribution.

\section{Data Analysis}

Analysis of Variance (ANOVA) was used to compare the effects of treatments on the measured properties. Mean differences were detected using Fisher's Least Significant Difference (F-LSD).
Some properties of the surface $(0-15 \mathrm{~cm})$ soil in 2009 presented in Table 1 shows that the texture was sandy clay loam whereas the organic matter content, $\mathrm{pH}, \mathrm{P}$, and the CEC were generally low to very low.

\section{Effects of treatments on soil organic matter (Om) content}

Plots under Panicum maximum had the highest Om content $(1.8 \%)$ at first sampling compared to the bare treatment plots which had the least $(0.4 \%)$. Similar trend was also observed at second sampling (Table 2). The Om content in plots under vegetative cover was significantly $(\mathrm{P}<0.05)$ higher than that in the bare plots, however there was no significant difference comparing the Om content of the various plots under vegetative cover.

\section{Effects of Treatment on Soil Physical Properties} Aggregate size distribution and stability

Fig.1a shows that the structure of the soil was significantly influenced by the grass and legume cover treatments. The effect of vegetative cover treatment on aggregate size distribution at first sampling showed that grass-treated plots had higher fractions of the aggregate size $>2.00 \mathrm{~mm}$ compared to legume-treated plots. The response followed the order: $\mathrm{Pp}>\mathrm{Ac}>\mathrm{Pm}>\mathrm{Cp}>\mathrm{Ce}$ $>$ Ps $>$ Be (Fig. 1a). The second sampling however showed a shift from this; the order was $\mathrm{Pp}>\mathrm{Pm}>\mathrm{Ps}>$ $\mathrm{Ac}>\mathrm{Cp}>\mathrm{Ce}>\mathrm{Be}$ (Fig. 1b). After the twenty four months of this experiment it was observed that on the average the percentage of the aggregates in the size range exceeding $1.00 \mathrm{~mm}$ was lowest $(20.5 \%)$ for soils under the bare treatment compared to those under grass $(48.4 \%)$ and legume $(35.5 \%)$, indicating that more than a half $(54 \%)$ of the aggregates of the bare plots were small sized $(<0.50 \mathrm{~mm}$ diameter) whereas about a half of the aggregates of grass treated plots were in the macro-aggregate range. Fig.1c shows that generally there was significant $(\mathrm{P}<0.05)$ increase in percent water-stable aggregates $>0.5 \mathrm{~mm}$ with time (years) in plots under vegetative cover compared to the bare plots.

\section{RESULTS \\ Initial Soil Properties}

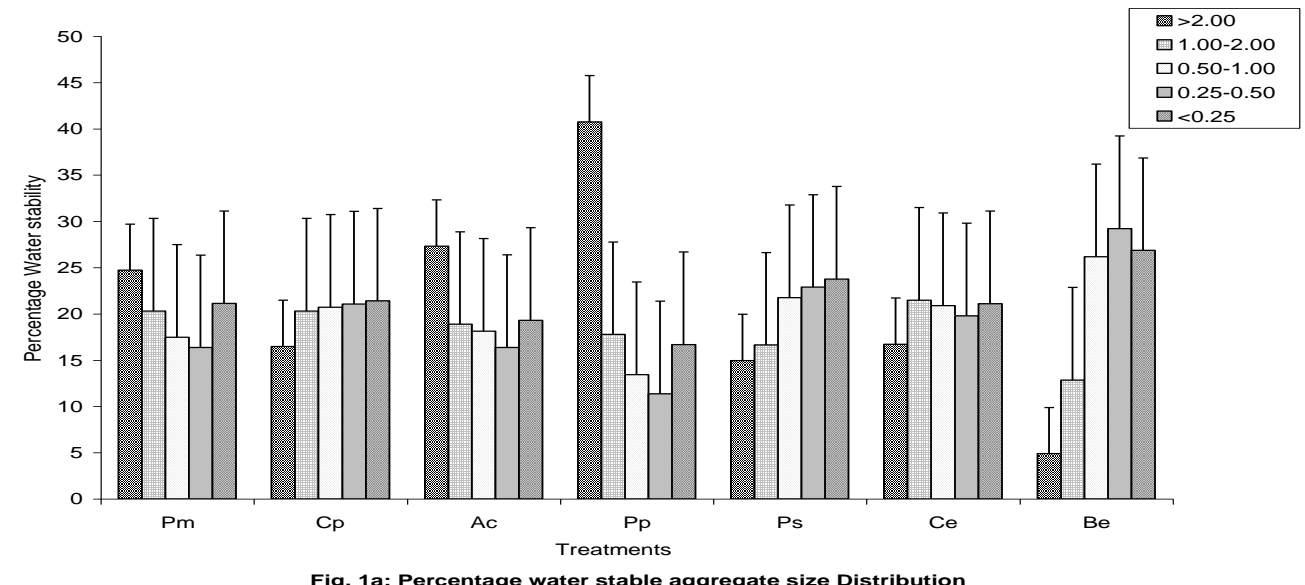

Where: $\quad \mathrm{Pm}=$ Panicum maximum

$\mathrm{Cp}=$ Cynodon plectostachyus

$\mathrm{Ac}=$ Axonopus compressus

$\mathrm{Pp}=$ Pennisetum purperum

Ps $=$ Pueraria phaseoloides

$\mathrm{Ce}=$ Centrosema pubescens

$\mathrm{Be}=$ Bare fallow 


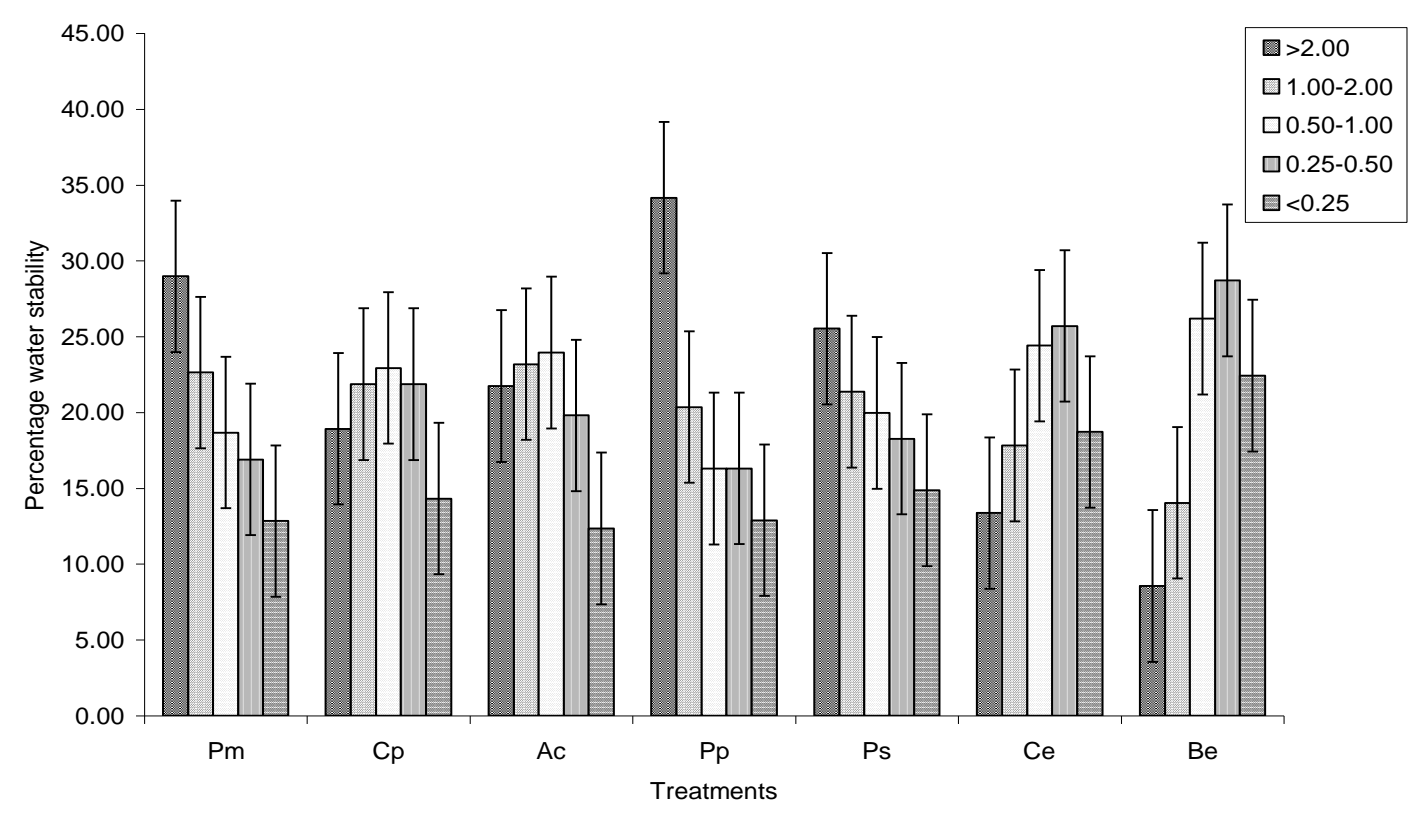

Fig. 1b: Percent Water Stable Aggregate Size Distribution (Second sampling)

Where: $\mathrm{Pm}=$ Panicum maximum

$\mathrm{Cp}=$ Cynodon plectostachyus

$\mathrm{Ac}=$ Axonopus comperum

$\mathrm{Pp}=$ Pennisetum purperum

Ps $=$ Pueraia phaseoloes

$\mathrm{Ce}=$ Centrosema pubescens

$\mathrm{Be}=$ Bare fallow

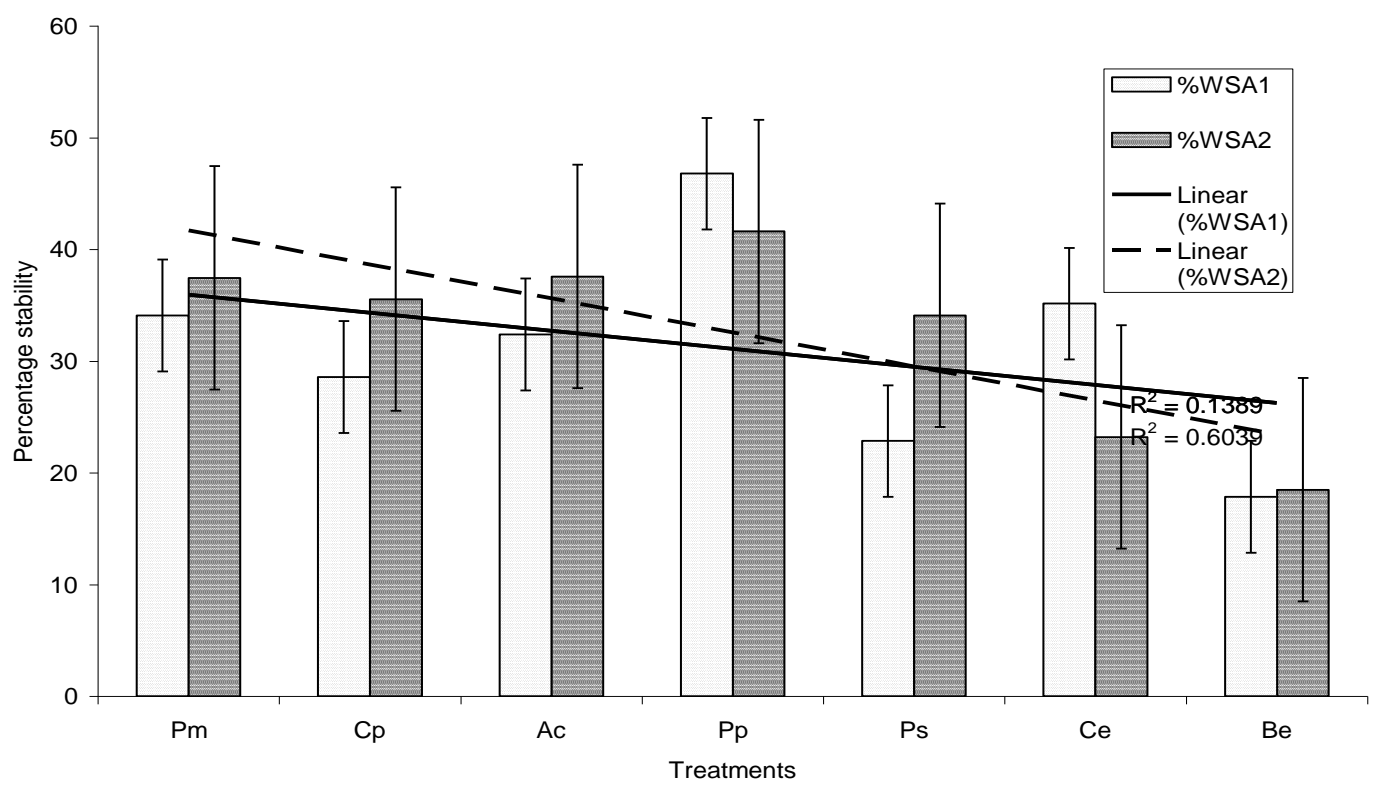

Fig. 1C: PERCENT WATER STABLE AGGREGATE $>0.5 \mathrm{~mm}$

Where: $\mathrm{Pm}=$ Panicum maximum

$\mathrm{Cp}=$ Cynodon plectostachyus

$\mathrm{Ac}=$ Axonopus comperum

$\mathrm{Pp}=$ Pennisetum purperum

$\mathrm{Ps}=$ Pueraia phaseoloes

$\mathrm{Ce}=$ Centrosema pubescens

$\mathrm{Be}=$ Bare fallow

WSA $=$ Percent water-stable aggregate $>0.5$ at first (1) and second (2) samplings 
Table 1: Properties of the surface $(0-15 \mathrm{~cm})$ soil at the start of the experiment

\begin{tabular}{ll}
\hline Soil property & Value \\
\hline Clay $(\%)$ & 26.8 \\
Silt $(\%)$ & 6.0 \\
Sand $(\%)$ & 67.2 \\
Bulk density $\left(\mathrm{Mg} \mathrm{m}^{-3}\right)$ & 1.32 \\
Saturated hydraulic conductivity $\left(\mathrm{cm} \mathrm{h}_{-1}\right)$ & 7.46 \\
Organic carbon $(\%)$ & 0.67 \\
Total N $(\%)$ & 0.065 \\
$\mathrm{pH}\left(\mathrm{H}_{2} \mathrm{O}\right)$ & 4.5 \\
$\mathrm{CEC}(\mathrm{cmo1} / \mathrm{kg}$ soil) & 5.12 \\
$\mathrm{Ca}(\mathrm{cmol} / \mathrm{kg} \mathrm{soil})$ & 2.35 \\
$\mathrm{Mg}(\mathrm{cmo1} / \mathrm{kg} \mathrm{soil})$ & 0.51 \\
$\mathrm{~K}(\mathrm{cmol} / \mathrm{kg}$ soil) & 0.12 \\
Available P $(\mathrm{ppm})$ & 7.1 \\
\hline
\end{tabular}

Table 2.Effect of treatments on the organic matter content of the Soil

\begin{tabular}{lll}
\hline & & Om\% \\
\cline { 2 - 3 } Treatment & 1 & 2 \\
\cline { 2 - 3 } & & \\
Panicum maximum & 1.77 & 1.64 \\
Cynodon plectostachyus & 1.38 & 1.61 \\
Axonopus compressus & 1.46 & 1.62 \\
Pennisetum purpureum & 1.53 & 1.44 \\
Pueraria phaseoloides & 1.56 & 1.61 \\
Centrosema pubescens & 1.51 & 1.42 \\
Bare & 0.41 & 0.58 \\
LSD 0.05 & 0.40 & 0.32 \\
\hline
\end{tabular}

1 and $2=$ First and second year sampling respectively

Table 3: Effect of treatments on mean-weight diameter $(\mathrm{mm})$ of soil aggregates

\begin{tabular}{lll}
\hline Treatment & MWD 1 & MWD3 \\
\hline Panicum maximum & 1.36 & 1.54 \\
Cynodon plectostachyus & 1.12 & 1.24 \\
Axonopus compressus & 1.43 & 1.34 \\
Pennisetum purpureum & 1.81 & 1.66 \\
Pueraria phaseoloides & 1.04 & 1.56 \\
Centrosema pubescens & 1.14 & 1.04 \\
Bare & 0.70 & 0.83 \\
LSD 0.05 & 0.519 & 0.476 \\
\hline
\end{tabular}

MWD1 = Mean-weight diameter at first sampling

MWD2 = Mean-weight diameter at second sampling

Table 4 Potential Structural Deformation Index (PSDI) and Degree of Structural Enhancement (DSE)

\begin{tabular}{lcc}
\hline Treatment & PSDI (\%) & DSE (\%) \\
\hline Panicum maximum & 17.56 & 47.34 \\
Cynodon plectostachyus & 20.13 & 33.27 \\
Axonopus compressus & 16.51 & 44.56 \\
Pennisetum purperum & 14.63 & 55.67 \\
Pueraria phaseoloides & 24.03 & 39.55 \\
Centrosema pubescens & 29.40 & 27.17 \\
Bare & 52.21 & - \\
LSD $_{\mathbf{0 . 0 5}}=\mathbf{2 . 8 2}$ & & \\
\hline
\end{tabular}


Table 3 shows that the treatments had significant effects on the mean weight diameter of the soil aggregates. In the first year, values varied from 0.70 to $1.81 \mathrm{~mm}$ whereas in the second year values ranged from 0.83 to $1.66 \mathrm{~mm}$. Plots treated with Panicum maximum were consistently more stable compared to the other vegetative cover treatment plots, while Soils under vegetative cover generally showed higher mean weight diameter (structural stability) in relation to bare treatment plots.

Soil aggregates under grass treatment (Table 4) showed the lowest range of PSDI values (14.63 $20.13 \%$ ) compared to aggregates under legume treatment $(24.07-27.17 \%)$. Plots under vegetative cover were on the average twice more stable to raindrop impact deformation compared to the bare treatment plots. All the vegetative cover treatments contributed to the structural enhancement of the soil under these treatments as shown by the positive values of their DSE. Pennisetum purpureum, however recorded the highest contribution to soil structural enhancement.

\section{DISCUSSION}

The sandy clay loam texture of the experimental site is a reflection of the parent material which according to Akamigbo and Asadu (1983) is false bedded sandstone. No change in soil texture was expected following treatment since the dominant particles from parent materials determine soil textural class (Akamigbo and Asadu, 1983). The low to very low organic matter content, $\mathrm{pH}, \mathrm{P}$ and $\mathrm{CEC}$ is typical of depleted tropical soils subjected to high organic matter decomposition rates and high leaching following intense rainy activities. The low values of the available $\mathrm{P}$ in particular, reflect the widespread phosphate deficiency in the soils of the region (Akamigbo and Igwe, 1990).

The significantly $(\mathrm{P}<0.05)$ higher organic matter content of plots under vegetative cover (grass and legume) explains why such plots presented more of larger aggregates against the predominantly small sized aggregates of the bare treatment plots. Obi (1999) obtained similar results working with grass and legume on a similar soil. It has been established that organic matter among other functions, serves to bind soil particles together into aggregates. This also explains why plots under vegetative cover were more resistant to the disaggregating/deformation impact of water (shown by PSDI values).

The predominantly higher macro aggregate composition of plots under grass treatments compared to plots under legume may be largely due to the influence of root mass than leave cover. The vigorous root system of the grasses as compared to that of the legumes may have conferred on grassed plots a superior protection against the shattering effect of rain drops incident on the soil. In addition the higher $\mathrm{C} / \mathrm{N}$ ratio of grasses over legumes ensures higher organic matter resilience (Dabney et. al., 2001) which ensures a comparatively more lasting stability of grass treated soils as against legume treatment. Apart from plots under Pennicetum purpureum, other plots with high composition of macro aggregates did not expectedly translate to higher mean weight diameter, this cannot be presently explained. The higher mean weight diameter exhibited by soil particles under vegetative cover treatment is also connected to the protective effect of organic matter on soil particles. While there were no statistical differences in the organic matter content of plots under cover treatments, the structural stability indices showed differences; this raises strong indication about some qualitative and quantitative factors which have been found to determine organic matter effect on soil structural stability, these may include lignin, humic acid and humin content of such organic materials (Piccolo and Mbagwu, 1990). Increased soil structural stability will improve the soil's capacity to carry machines with comparatively lower risk of soil compaction and improve field accessibility (Onwualu and Ahaneku, 2001), among other benefits

\section{CONCLUSION AND RECOMMENDATION}

The results of this study therefore indicate that the use of cover crops is effective in increasing the structural stability of this degraded 'acid sand' Ultisol and other similar soils of the region. The grasses (Panicum maximum in particular) gave higher results.

This work therefore recommends the adoption of Panicum maximum as a crop in the cover management system of these soils against structural degradation. Furthermore, since this region is endowed with vast and diverse vegetation, this work opens up a new lead for the trial of other species, multiplication and use of those with excellent soil structural enhancement properties.

\section{REFERENCES}

Ahamefule,H.E. and Mbagwu,J.S.C.2007.Effects of phosphorus and four tillage-mulch systems on the physico-chemical properties of an Ultisol in eastern-Nigeria. Agro-Science.6:25 - 32 .

Akamigbo, F.O.R. and Asadu, C.L.A., 1983. Influence of parent material on the soils of south eastern Nigeria. East African Forest. J. 48: 81-91.

Akamigbo, F.O.R., and Igwe, C.A., 1990. Morphology, genesis and taxonomy of three soil series in eastern Nigeria. Samaru Journal of Agricultural Research. 7, 33-48.

Clarke, A.L., Greenland, D.J. and Quirk, J.P. 1967. Changes in some physical properties of the surface of an impoverished Red-Brown earth under pasture. Austr. J. Soil Sci. Res. 5, 5968.

Dabney, S.M. 1996. Cover crop impacts on watershed hydrology. Soil and Water Conservation, 53 (3), 207-213.

Dabney, S.M., J.A. Delgado, and D.W. Reeves. 2001. Using winter cover crops to improve soil and water quality. Community of Soil Science Plant Analysis, 32 (7\&8), 1221-1250.

Food and Agricultural Organisation (FAO) Bulletin. 1990. An International Action Programme on Water and Sustainable Agricultural Development.

Greenland, D.J. 1971. Interactions between Humic and Fulvic acids and clay. Soil Sci., 3: $34-41$. 
Juo, A.S.R. and Lal, R. 1977. The effects of Fallow and Continuous Cultivation on the chemical and physical properties of an Alfisol in Western Nigeria. Plant Soil 47: 567 - 584.

Kemper, D.W. and Rosenau, R.C. 1986. Aggregate stability and aggregate size distribution. In: Methods of soil analysis, part 1, ed A Klute, ASA -SSSA Medison Wisconsin 425-442.

Lal, R. And Falayi, O. 1979. Effect of aggregate size and mulching on erodibility, crusting and crop emergence. In: Lal, R. And D.J. Greenland (eds) Soil physical properties and crop production in the tropics. New York: John Wiley.

Mbagwu, J.S.C. and Bazzoffi, P. 1998. Soil characteristics related to resistance of breakdown of dry aggregates by water drops. Soil and Tillage Research 45: 133 - 145.

McBride, T.P (ed),. 1990. Tropical Soils Technical Report.1988- 1989. North Carolina State University. Raleigh, NC, USA. 357pp

Obi, M.E., 1982. Runoff and soil loss from an oxisol in south eastern Nigeria under various management practices. Agric. water Management 5:193-203.

Obi, M.E., 1999. The Physical and Chemical Responses of a degraded sandy clay loam soil to cover crops in south-eastern Nigeria. Plant and Soil. 211: $165-172$.

Onwualu,A.P. and Ahaneku,I.E.2001.Conservation and conventional tillage effects on soil properties and soybean production. AgroScience.2(2):26 - 36 .

Page, A.L., Millernad, R.H. and Keerney (eds). 1986. Methods of analysis part II, $2^{\text {nd }}$ edition. Agron. Monogram No. 9. American Society of
Agronomy and Soil Science Society of America. Medison WI.

Piccolo, A. And Mbagwu, J.S.C. 1990. Effects of different organic amendments on soil aggregate stability and molecular sizes of humic substances. Plant and Soil 123:27-37.

President's Science Advisory Committee. 1967. The World Food Problems, Vol. 2. The White house, Washington DC, USA. Salako,F.K. 2001.Structural stability of an Alfisol under varios fallow management practices in south-western Nigria. Land Degradation and Development.12:319 - 328.

Salako,F.K , Olowokere F. A., Tian,G. Kirchhof,G and Osiname,O.2007.Ground cover by three crops cultivated on marginal lands in south-western Nigeria and implication for soil erosion.Spanish.J. Agric. Res.5(4):497 - 505.

Theng, B.K. 1976. Formation and properties of claypolymer complex. New York: Elsevier USDA Soil Survey Staff. 1975. Soil Taxonomy. Agriculture Hand book 436. Soil Conservation Services. Washington DC.

Walker, D., D. Baumgartner, K. Fitzsimmons, and C.P. Gerber. 2006. Chapter 18: Surface Water Pollution, In Environment \& Pollution Science. Eds. I.L. Pepper, C.P. Gerber, and M.L. Brusseau. p. 283.

Wilkinson, G.E. 1975. Effects of grass fallow Rotations on Infiltration of water into savannah zone soil of Nigeria. Tropical Agric. 52, 97-103.

Wilkinson, G.E. and Aina, P.O. 1976. Infiltration of water into two Nigerian soils under secondary forest and subsequent arable cropping. Geoderma 15, 51-59. 